\title{
Changes in volatile compounds, microstructure and texture of sharri cheese during maturation
}

\author{
Erhan Sulejmani \\ Department of Food Technology and Nutrition, University of Tetova, Macedonia
}

Correspondence: Erhan Sulejmani, Department of Food Technology and Nutrition, University of Tetova, I200, Tetovo, Macedonia, Tel 38976466 139, Email sulejmani_e@hotmail.com

Received: January 22, 2018 | Published: January 30, 2018

Copyright@ 2018 Sulejmani. This is an open access article distributed under the terms of the Creative Commons Attribution License, which permits unrestricted use, distribution, and reproduction in any medium, provided the original author and source are credited.

\begin{abstract}
Changes on volatile profile and microstructure during manufacture and maturation were determined in samples of Sharri mountain cheese obtained from farm batches in the main production area in Macedonia. These cheeses were analyzed at 1, 120 and 150 days of maturation for texture profile, volatile compounds and microstructure properties. A total of 82 volatile compounds including esters (20), acids (16), alcohols (15), terpenes (7), aldehydes (7), ketones (5) and miscellaneous (12) were identified by SPME/GC-MS. Hexanoic and butanoic acid were the most important carboxylic acids present in Sharri cheese. The highest concentration of carboxylic acids at cheeses were detected until 120 days of ripening, its concentration then decreased during 150 days of ripening. Volatiles and the textural parameters of the cheeses were significantly influenced by the maturation process $(\mathrm{P}<0.05)$. Higher levels of springiness were observed in at the beginning of maturation however stiffness, showed a large decrease during the maturation. On the other hand, small differences in adhesiveness were registered throughout the entire maturation period. Similar behaviors were also found in microstructure. This fact could be, among other factors, consequences of differences in technologies and maturation conditions of different producers which are not well standardized, as there are neither defined protocols for this procedure.
\end{abstract}

Keywords: volatile compounds, textural profile, SPME/GC-MS, microstructure

\section{Introduction}

During maturation, several biochemical events (primarily proteolysis, glycolysis, and lipolysis) as well as slow solubilization of some of the residual CCP (colloidal calcium phosphate) change curd from a rubbery, bland product to mature cheese with a characteristic flavor, texture, and aroma. ${ }^{1}$ Study of the flavor is useful to define cheese quality, to characterize the cheese linking with its typical sensorial features and its original environment, to evaluate changes during the maturation process and to detect off-flavors; knowledge of mechanism which leads to flavor also enables standardization of cheese manufacture and better control of the process. ${ }^{2}$ In cheese grading or judging, the physical properties are commonly identified in the terms "body" and "texture". By convention, in the dairy industry the term "body" denotes the consistency of the product (e.g., firmness, softness, cohesiveness, rubberiness, elasticity, plasticity, pastiness, brittleness, curdiness, crumbliness), whereas texture" refers to the relative number, type, and size of openings that can be observed visually (e.g., close, open, gassy, slit-openings, mechanical openness) or by the sense of touch (as in mealy/grainy) to reveal internal particles. ${ }^{3}$ Different cheese varieties have a wide range of textural characteristics, and these also greatly change with aging due to proteolysis, moisture loss, salt uptake, $\mathrm{pH}$ change, and the slow dissolution of residual $\mathrm{Ca}$ associated with $\mathrm{CN}$ particles. Cheese composition (i.e., moisture, protein, fat, $\mathrm{NaCl}$, milk salts, and $\mathrm{pH}$ ) has a major impact on the body and texture of cheeses and is mainly controlled by the initial composition of the cheese milk (which is modified by the method used for milk standardization) and the manufacturing protocols (e.g., $\mathrm{pH}$ at renneting and draining, size of curd particles, cooking temperature, method of salting) used for cheese making ${ }^{4}$. The main factors influencing the deformation at fracture are $\mathrm{pH}$ (and the amount of $\mathrm{Ca}$ associated with the $\mathrm{CN}$ ) with cracks more likely to occur if the $\mathrm{pH}$ is below 5.15 and if gas is produced at a later stage of maturation (because proteolysis reduces the fracture strain). ${ }^{5-6}$

Sharri cheese is an authentic product to its hard consistence and exceptionally salty taste and it is originated from the territory of Sharri mountain, where it was manufactured in the past years on the pasture land exclusively from ewe's milk. The 'Sharri' designation is originated from the production area of Sharri mountain in Macedonia and Kosovo. ${ }^{7}$ It is artisanal made using raw ewe or cow milk, or mixtures thereof, where no starter is added. Few studies are available on the gross compositional or microbiological status of the cheese sold in retail shops. ${ }^{89}$ To the author knowledge there is no information available on aroma profile, texture and microstructure profile during maturation. The objective of the present work was to investigate the changes on volatile properties, textural, and microstructure during maturation process and their relationships. 


\section{Materials and methods}

\section{Materials and cheese manufacture}

Raw ewe milk supplied from mountain area of Vejce village from Tetovo region (R.Macedonia) was used in Sharri cheese making. Two cheese-making trials were performed for the manufacture of Sharri cheese similarly as described previously by Rysha and Delaš. ${ }^{7}$

\section{Gross chemical composition}

Cheese samples for gross chemical composition were analyzed at the first day of ripening. The $\mathrm{pH}$ was measured by means of a combined electrode $\mathrm{pH}$-meter (Thermo Orion, Asheville, USA). Dry matter was assessed by a gravimetric method drying cheese samples at $102^{\circ} \mathrm{C} .{ }^{10}$ Fat content was analysed by butyrometric method according to Van Gulik using a butyrometer ${ }^{11}$ and nitrogen by Kjeldahl method with conversion to protein content using a factor of $6.38 .{ }^{12}$

\section{Headspace analysis of volatiles}

Analysis of the volatiles were performed by a static solid-phase microextraction method described by Hayaloglu et al., ${ }^{13}$ using a GC-MS system (Shimadzu Corp.). The identifications were based on comparing mass spectra of unknown compounds with those in the mass spectral library of John Wiley and Sons Inc. (2005) and the National Institute of Standards and Technology/Environmental Protection Agency/National Institutes of Health mass spectral library. Identifications were also confirmed by comparing retention times with reference standards when available. A total of 33 authentic standard compounds (Sigma Chemical Co., St. Louis, MO, USA) were used to confirm the identities of volatile compounds in the cheese samples. The concentrations were calculated by the comparison of the peak areas of the internal standard containing an $81 \mathrm{mg} / \mathrm{kg}$ mixture of 2-methyl-3-heptanone and 2-methyl-1-pentanoic acid in methanol (Sigma-Aldrich Co.) and unknown compounds.

\section{Microstructure}

The samples content and morphology were detected by the energy dispersive X-ray spectroscopy (EDX, BRUKER) inserting the sample parts on a sample holder in vacuum chamber of measurement system. The parts were attached to the holder with conductive adhesive tape. The structure analysis was made with the X-ray diffraction (XRD, Panalytical) technique using $\mathrm{Cu}$-Ka radiation and scanning $2 \theta$ between $40^{\circ}$ and $100^{\circ}$. Surface structure of the samples were observed by the scanning electron microscope (SEM, ZEISS EVO LS 10) at the same time and the situations with the EDX measurements

\section{Statistical analysis}

Data obtained from texture and volatiles were subjected to analysis of variance using the GLM procedure of SAS (version 8.0). Duncan's Multiple Range Test was used to determine the statistically different groups. The trial including cheese-making was repeated twice and the level of confidence was at least $95 \%(P<0.05)$.

\section{Results and discussion}

\section{Chemical composition and $\mathrm{pH}$ of the cheese}

Chemical composition of 1-d old Sharri cheeses ranged between 5.60 - 5.62 for $\mathrm{pH}, 57.52-61.17 \%$ for total solid, $31.00-30.00 \%$ for fat, $24.81-26.60 \%$ for protein and $0.47-0.29 \%$ for salt, respectively. The gross chemical composition of the cheeses showed similarities to those reported previously for Sharri cheese. ${ }^{8}$

\section{Changes in volatile composition of Sharri cheeses during maturation}

The volatile components present in these Sharri-type cheese samples consist of 20 esters, 16 acids, 15 alcohols, 7 aldehydes, 7 terpenes, 5 ketones and 12 miscellaneous (Table 1).

Most of these components had already been reported in other types of brined cheese. ${ }^{13,14}$ Some of the volatile components present in this study increased during maturation, while others decreased or fall to unquantified levels. Twenty esters were identified, and they were all (except 5 esters) significantly affected by the maturation process (Table 1). The important contribution of esters to cheese flavours is not in doubt, since short chain esters have a perception thresholds 10 times lower than alcohols from which they are derived. Like Gokceada and Mihalic cheeses ethyl and mehyl esters were the most prevalent esters in this cheese. ${ }^{13}$ Large quantities of ethanol and esters are associated with fruity flavors. ${ }^{15}$ Methyl butyrate $(123 \mu \mathrm{g} / 100 \mathrm{~g})$ and methyl hexanoate $(106 \mu \mathrm{g} / 100 \mathrm{~g})$ were the most abundant esters in Sharri cheese. Sixteen carboxylic acids were identified in both Sharri cheese variants with acetic, butanoic, hexanoic and heptanoic acids being the main ones. It is described that the main source of free fatty acids is lipolysis but they can also result of the metabolism of lactose, and is biosynthesized directly from acetyl CoA, or formed from amino acid conversion. ${ }^{16}$ Free fatty acids can be involved in cheese aroma or in rancidity defect when they are present in very large amount. ${ }^{16-17}$ Lipolysis is partially extensive in Sharri cheese varieties because of the rennet and the lipoprotein lipase (LPL) present in raw milk used for its manufacture.

The fatty acids determine the flavour of cheese, in particular the short chain fatty acids impart a desirable piquant taste. ${ }^{15}$ More intense overall aroma has been reported for raw milk cheeses compared with pasteurized milk cheeses. ${ }^{18,19}$ The principal acids were butyric $(6136 \mu \mathrm{g} / 100 \mathrm{~g})$ and hexanoic $(7944 \mu \mathrm{g} / 100 \mathrm{~g})$ and were identified at higher levels in Sharri cheese samples during maturation (Table 1). At day 120 of maturation, most of acids were at higher concentration in Sharri cheese. Fifteen alcohols were identified in Sharri cheese samples and their concentrations almost increased during ripening. Only three alcohols were significantly affected by the maturation process. Among these alcohols ethanol and 3-methyl-1-butanol were detected at higher level at the beginning of maturation. 
Table I Mean values \pm SD of volatile compounds ( $\mu \mathrm{g} / \mathrm{I} 00 \mathrm{~g}$ of cheese) identified in Sharri mountain cheeses after I, I 20 or I50 days of ripening

\begin{tabular}{|c|c|c|c|c|c|}
\hline Compounds & $\mathbf{R} \mathbf{I}$ & Day I & Day 120 & Day I50 & $\mathrm{P}$ \\
\hline \multicolumn{6}{|l|}{ Esters } \\
\hline Methyl formate & 784 & $1.46 \pm 0.73$ & ND & $4.15 \pm 0.60$ & $*$ \\
\hline Methyl acetate & 835 & $9.98 \pm 0.12$ & $0.29 \pm 0.03$ & $0.55 \pm 0.42$ & $*$ \\
\hline Ethyl acetate & 894 & $19.75 \pm 0.08$ & $37.75 \pm 4.52$ & ND & $*$ \\
\hline Methyl propanoate & 917 & $0.22 \pm 0.32$ & $0.44 \pm 0.02$ & ND & $*$ \\
\hline Methyl butyrate & 991 & $122.58 \pm 36.7$ & ND & $4.46 \pm 4.28$ & $*$ \\
\hline 2-Methylpropyl acetate & 1020 & ND & $1.4 \pm 0.02$ & $2.35 \pm 1.17$ & NS \\
\hline 3-Methyl butanoate & 1027 & ND & ND & $0.34 \pm 0.13$ & $*$ \\
\hline Ethyl butyrate & 1041 & $3.87 \pm 1.02$ & $21 \pm 0.1$ & $18.46 \pm 12.5$ & $*$ \\
\hline Methyl pentanoate & 1091 & $0.24 \pm 0.34$ & $0.38 \pm 0.07$ & ND & $*$ \\
\hline Methyl valerate & 1093 & ND & $0.19 \pm 0.03$ & $1.42 \pm 1.33$ & $*$ \\
\hline Methyl hexanoate & 1196 & $106 \pm 24$ & $5.7 I \pm 0.39$ & $4.32 \pm 0.74$ & $*$ \\
\hline Ethyl capronate & $|24|$ & $1.28 \pm 1.81$ & $20.40 \pm 2.4 I$ & $20.59 \pm 6.85$ & NS \\
\hline Ethyl hexanoate & 1243 & $1.43 \pm 1.2$ & ND & ND & $*$ \\
\hline Isoamyl butyrate & 1274 & $0.72 \pm 0.02$ & $3.60 \pm 0.18$ & $3.29 \pm 1.45$ & NS \\
\hline Methyl heptanoate & 1297 & $0.28 \pm 0.10$ & $1.04 \pm 0.07$ & ND & $*$ \\
\hline Methyl octanoate & 1404 & $19.76 \pm 3.23$ & $2.52 \pm 0.26$ & $1.27 \pm 0.72$ & $*$ \\
\hline Ethyl octanate & 1450 & $0.22 \pm 0.005$ & $4.17 \pm 0.14$ & $3.20 \pm 1.05$ & NS \\
\hline Isopentyl hexanoate & 1476 & $0.38 \pm 0.17$ & $1.01 \pm 0.02$ & $0.59 \pm 0.37$ & NS \\
\hline Methyl decanoate & 1616 & $4.76 \pm 0.37$ & $2.89 \pm 0.03$ & $1.63 \pm 0.24$ & $*$ \\
\hline Ethyl decanoate & 1659 & ND & $0.7 I \pm 0.00 I$ & $0.63 \pm 0.20$ & $*$ \\
\hline Total & & 294 & 104 & 68 & \\
\hline \multicolumn{6}{|l|}{ Acids } \\
\hline Acetic acid & 1462 & $|54 \pm 6|$ & $2096 \pm 54$ & $|27| \pm 444$ & NS \\
\hline Propionic acid & $|55|$ & ND & ND & $0.7 \pm 0.2$ & NS \\
\hline Isobutyric acid & 1580 & $101 \pm 38$ & $135 \pm 14$ & $86 \pm 37$ & NS \\
\hline Butyric acid & 1641 & $878 \pm 452$ & $6136 \pm 449$ & $4662 \pm|7| 4$ & NS \\
\hline Pentanoic acid & 1684 & $389 \pm 180$ & $348.21 \pm 22.7$ & $221 \pm 96$ & NS \\
\hline 2,2-Dimethyl-butanoic acid & 1718 & ND & $44 \pm 4.2$ & $24 \pm 35$ & NS \\
\hline Hexanoic acid & 1864 & $877 \pm 306$ & $7944 \pm 803$ & $5991 \pm 2491$ & NS \\
\hline 2-Ethyl butyric acid & 1955 & $9 \pm 5$ & ND & ND & NS \\
\hline Heptanoic acid & 1974 & ND & $77 \pm 8$ & $48 \pm 32$ & $*$ \\
\hline Octanoic acid & 2079 & $414 \pm 85$ & $3692 \pm 396$ & $2362 \pm 1184$ & NS \\
\hline Pelargonic acid & 2180 & $4 \pm 6.2$ & $22.0 \mathrm{I} \pm 0.4$ & $3 \pm 2$ & NS \\
\hline 2-Ethyl caproic acid & 2226 & $11 \pm 2.6$ & $5 \pm 3$ & $5 \pm 3$ & NS \\
\hline Decanoic acid & 2277 & $97 \pm 17.2$ & $1283 \pm 128$ & $806 \pm 458$ & NS \\
\hline 9-Decenoic acid & 2336 & $3 \pm 3.7$ & $30 \pm 2$ & $20 \pm 19$ & $*$ \\
\hline Benzoic acid & 2480 & ND & $22 \pm 33$ & $25 \pm 17$ & NS \\
\hline Dodecanoic acid & 2491 & ND & $56 \pm 2$ & $39 \pm 25$ & NS \\
\hline Total & & 2937 & 21896 & 15570 & \\
\hline
\end{tabular}


(Table I continuous..)

Alcohols

3-Methyl-I-heptanol

Ethanol

2-Butanol

2-Methyl - I-propanol

2-Pentanol

I-Butanol

|-Penten-3-ol

3-Methyl-I-butanol

I-Pentanol

2-Heptanol

3-Methyl-2-buten-I-ol

2-Pentanol

I-Hexanol

Octandiol

Benzeneethanol

Total

$\begin{array}{ll}933 & 0.6 \pm 0.6 \\ 984 & 4 . I \pm 2.9\end{array}$

ND

$38 \pm 7$

$15.83 \pm 0.29$

$15 \pm 2$

ND

ND

NS

$1094 \quad 2.2 \pm 1.2 \quad 7.63 \pm 0.14$

7. $1 \pm 0.6$

NS

1122 ND

$8.68 \pm 0.43$

$0.2 \pm 0.03$

NS

II $55 \quad 0.1 \pm 0.1$

$0.38 \pm 0.08$

$0.2 \pm 0.1$

NS

II6I $0.1 \pm 0.1$

$1.07 \pm 0.01$

$1.02 \pm 0.3$

NS

$1214 \quad 22.15 \pm 3.1$

$91.02 \pm 1.63$

$77 \pm 2$

$1253 \quad 0.7 \pm 0.4$

$3.69 \pm 0.53$

$2.02 \pm 1.2$

NS

$1323 \quad 0.21 \pm 0.12$

$0.38 \pm 0.04$

$0.2 \pm 0.1$

NS

1327 ND

$0.28 \pm 0.03$

$0.26 \pm 0.05$

NS

1352 ND

$1359 \quad 0.22 \pm 0.31$

$0.22 \pm 0.07$

$0.4 \pm 0.3$

NS

I. $.02 \pm \pm 0.02$

ND

NS

$1493 \quad 0.60 \pm 0.85$

3. $18 \pm 0.01$

ND

NS

$1947 \quad 16.83 \pm 0.17$

$3.01 \pm 0.73$

$2.33 \pm 0.73$

NS

49.05

137

155

Aldehydes

Hexanal

Butanal

Propanal

2-Methyl - propanal

2-Methyl -butanal

3-Methyl - butanal

Benzaldehyde

Total

$\begin{array}{lll}747 & 7.45 \pm 9.24 & \text { ND } \\ 756 & 7.24 \pm 10.25 & \text { ND }\end{array}$

$804 \quad 0.60 \pm 0.86$

$0.34 \pm 0.01$

$82|\quad| 5.9| \pm 22.5| \quad 0.78 \pm 0.10$

$919 \quad 10.43 \pm 14.76$

$12.57 \pm 0.68$

$923 \quad 71.02 \pm 38.94$

$1.28 \pm 0.15$

$0.36 \pm 0.019$

4. $10 \pm 2.3$

14

$0.64 \pm 0.91$

ND

ND

ND

$0.36 \pm 0.33$

$1.21 \pm 0.002$

$0.17 \pm 0.07$

NS

115

2

Terpenes

I,3-Octadiene

$\alpha$-Pinene

2- $\beta$-Pinene

$\beta$-Myrcene

D-Limonene

Sabinene

p-Cymene

Total

$\begin{array}{ll}963 & 0.10 \pm 0.15 \\ 1027 & 2.34 \pm 0.23 \\ 1107 & 0.82 \pm 0.06 \\ 1170 & 2.81 \pm 2.90 \\ 1210 & 54.7 \pm 22.6 \\ 1121 & 0.1 \pm 0.1 \\ 1282 & 0.8 \pm 0.15\end{array}$

ND

$0.45 \pm 0.27$

NS

$2.05 \pm 0.11$

$13.59 \pm 16.42$

NS

$0.27 \pm 0.01$

$0.21 \pm 0.07$

NS

$0.37 \pm 0.04$

ND

$0.30 \pm 0.01$

$0.25 \pm 0.07$

ND

$0.40 \pm 0.06$

$0.67 \pm 0.11$

NS

61.7

3.2

15.5

Ketones

2-Propanone

2-Butanone

2-Pentanone

\section{3}

907

ND

I.6 60 . I

$9827.1 \pm 2.1$
$2.7 \pm 0.3$

$2.9 \pm 0.2$

$21.0 \pm 0.9$

$3.61 \pm 1.20 \quad *$
$4.91 \pm 1.90$

$9.24 \pm 4.82 \quad N S$ 


\begin{tabular}{|c|c|c|c|c|c|}
\hline 2-Heptanone & 1191 & $1.5 \pm 1.2$ & $7.7 \pm 0.1$ & $4.64 \pm 0.84$ & NS \\
\hline Acetoin & 1298 & $12.42 \pm 4$ & $32.2 \pm 0.4$ & $25.69 \pm 0.6$ & NS \\
\hline Total & & 22.7 & 66.6 & 48 & \\
\hline \multicolumn{6}{|l|}{ Miscellaneous } \\
\hline Carbon dioxide & & $3.27 \pm 3.33$ & ND & ND & $*$ \\
\hline Hexane & 729 & $186 \pm 28$ & $22 \pm 2$ & $5.8 \pm 0.6$ & $*$ \\
\hline Pentane & 732 & ND & $2.94 \pm 0.68$ & $3.3 \pm 1.1$ & $*$ \\
\hline Heptane & 764 & $0.6 \pm 0.6$ & $2.09 \pm 0.12$ & $1.9 \pm 0.3$ & NS \\
\hline Octane & 818 & $I \pm I$ & $4.02 \pm 0.005$ & ND & NS \\
\hline 4-Octene, (E)- & 849 & $0.52 \pm 0.3$ & $0.5 \mathrm{I} \pm 0.0 \mathrm{I}$ & $1.4 \pm 0.9$ & $*$ \\
\hline 3-Octene, (Z)- & 850 & $1.70 \pm 1.6$ & I. $77 \pm 0.05$ & $1.6 \pm 0.3$ & NS \\
\hline 2-Octene & 866 & $0.96 \pm 0.2$ & $0.65 \pm 0.07$ & $0.9 \pm 0.9$ & $*$ \\
\hline Toluene & 1047 & $23.4 \pm 4.8$ & $8.6 I \pm 0.31$ & $4.6 \pm 4.5$ & $*$ \\
\hline o-Xylene & 1156 & $0.3 I \pm 0.1$ & $0.26 \pm 0.10$ & ND & $*$ \\
\hline Styrene & 1273 & $2.9 \pm 2.86$ & $1.56 \pm 0.02$ & $0.51 \pm 0.29$ & $*$ \\
\hline Butyrolactone & 1667 & $1.12 \pm 0.08$ & $0.46 \pm 0.03$ & $0.1 \pm 0.1$ & $*$ \\
\hline Total & & 220 & 44.4 & 20.1 & \\
\hline
\end{tabular}

Mean data for Sharri cheese analyzed in triplicate. RI: retention index, ND: not detected, NS: not significant, $P$ : probability $* P<0.05 ; P$ is probability for ripening period (i.e., I, 120 or 150 days)

However, the relative abundance of 3-methyl-1- butanol was significantly increased during maturation in the Sharri cheeses. Alcohols are the principal chemical group in some ewe's milk cheeses, where ethanol in terms of quantity, is the main one..$^{20-23} 2$-butanol was identified only at the end of ripening (120,150 days). Probably higher heat treatment of the curd used during manufacturing of cheeses decreased the levels of total free amino acids, which are one of the precursors of ethanol by Strecker degradation that explains the lowest levels of ethanol found in Sharri cheeses. A very high abundance of 3-methyl-1-butanol was found at the $120^{\text {th }}$ day of maturation (Table 1). Other branched alcohols were not significantly affected by the maturation process. Seven aldehydes, were identified in cheese samples with 3-methyl-butanal, 2-methyl-butanal and 2-methyl-propanal being the main ones. No significant differences in concentrations of benzenaldehyde were found in the cheeses regardless of maturation time. 3-Methyl-butanal was present at higher levels in the cheese and is often correlated with the formation of off-flavors. Seven terpenes were detected in Sharri cheese and d-limonene is the principal terpene in the cheese (Table 1). On the $1^{\text {st }}$ day of maturation, the abundance of d-limonene in cheese was high $(54.7 \mu \mathrm{g} / 100 \mathrm{~g})$, but afterwards, this compound was not detected. $\beta$-myrcene and d-limonene were significantly decreased during the maturation process.

In total, five ketones were identified in the Sharri cheese samples with high abundance of 3-Hydroxy-2-butanone (acetoin), 2-pentanone and 2-butanone. 2-Propanone identified in Sharri cheese was significantly affected by the maturation process. The concentrations of methyl ketones in cheeses increased during the 120 days of maturation and then decreased rapidly probably due to the decrease of the microbial activity during the maturation. ${ }^{24}$ They are very important compounds for dairy products because they have very particular odours and low perception thresholds. 3-Hydroxy-2-butanone originates from citrate metabolism as a reduction of diacetyl by the action of lactic acid bacteria. ${ }^{25}$ The highest concentration of acetoin was detected at the $120^{\text {th }}$ day of maturation and its concentration then decreased until 150 day-old cheeses due to its reduction to butanone, as reported by Bertolino et al. ${ }^{26}$ Twelve miscellaneous compounds were identified in Sharri cheeses including alkanes, alkenes and aromatic compounds. Hexane was the main alkane identified in higher concentration in cheeses at the $1^{\text {st }}$ day of maturation $(186 \pm 28 \mathrm{~g} / 100 \mathrm{~g}$ of cheese); it's concentration decreased significantly during maturation. Alkanes originated from lipid oxidation although they could also come from feed. ${ }^{20-21}$ Toluene was the second most abundant of the aromatic hydrocabones, present at higher levels cheese. Some of these compounds came from the degradation of milk carotene, although did not discard an aromatic amino acid degradation origin. It was reported that a wide number of hydrocarbons have been isolated at high levels in Feta-type ${ }^{22}$ and other ewe's milk semi-hard cheeses. ${ }^{27}$

\section{Changes in the texture profile analysis (Tpa) of sharri cheeses during maturation}

Texture parameter changes of Sharri cheeses analyzed during the 1 - 150 days of maturation are shown in Table 2. Cohesiveness, gumminess and chewiness values significantly increased during the maturation of cheese however the stiffness decreased probably due to the proteolysis process. ${ }^{28}$ Gumminess increased during maturation of other cheeses such as Ibores goat cheese ${ }^{29}$ and Castelmagno PDO. ${ }^{26}$ 
Table 2 Textural properties of Sharri mountain cheese during maturation

\begin{tabular}{|c|c|c|c|c|}
\hline Parameters & & Day 1 & Day 120 & Day 150 \\
\hline Cohesiveness & & $0.20 \pm 0.4^{\mathrm{a}}$ & $0.50 \pm 0.3^{\mathrm{a}}$ & $0.92 \pm 0.0^{\mathrm{b}}$ \\
\hline Springiness & $\mathrm{mm}$ & $0.49 \pm 0.08^{\mathrm{a}}$ & $0.41 \pm 0.05^{\mathrm{a}}$ & $0.42 \pm 0.01^{\mathrm{b}}$ \\
\hline Gumminess & $\mathrm{N}$ & $10.70 \pm 22.5^{\mathrm{a}}$ & $10.33 \pm 6.85^{\mathrm{a}}$ & $46.37 \pm 0.2^{\mathrm{b}}$ \\
\hline Chewiness & $\mathrm{Nmm}$ & $4.33 \pm 10.2^{\mathrm{a}}$ & $4.37 \pm 2.72^{\mathrm{a}}$ & $19.56 \pm 0.6^{b}$ \\
\hline Fracture force & $\mathrm{N}$ & $1.30 \pm 0.11^{\mathrm{b}}$ & $0.81 \pm 0.07^{\mathrm{a}}$ & $1.37 \pm 0.12^{\mathrm{a}}$ \\
\hline Adhesiveness & $\mathrm{Nmm}$ & $0.03 \pm 0.04^{\mathrm{a}}$ & $0.02 \pm 0.01^{\mathrm{a}}$ & $0.02 \pm 0.02^{\mathrm{a}}$ \\
\hline Stiffness & $\mathrm{N}$ & $102.92 \pm 1.60^{\mathrm{b}}$ & $55.22 \pm 4.17^{\mathrm{a}}$ & $70.5 \pm 18.32^{\mathrm{a}}$ \\
\hline
\end{tabular}

a,bMeans \pm SD within a row with no common superscript lowercase letters differ $(P<0.05)$

\section{Changes in the microstructure}

Microstructure of cheeses was screened by scanning electron microscopy and the 1,000 magnification images are shown in Figure 1 . The smaller pores in cheeses at $1^{\text {st }}$ day of maturation were evident probably microstructure at 150 days of storage demonstrated that the protein matrix had stretched, which was affected by proteolysis. The type of coagulant slightly may influence the microstructure of Sharri mountain cheeses. The cheeses that contained smaller openings had
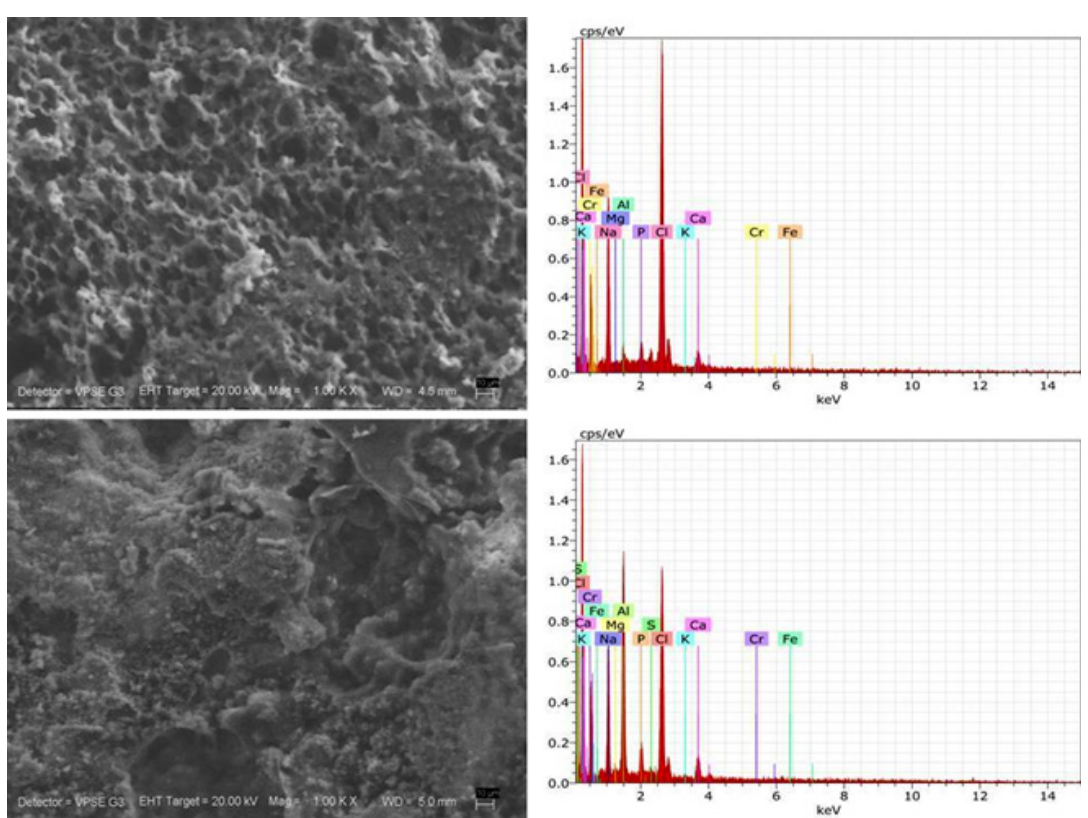

Figure I Scanning electron microscope micrographs at magnification x 1000 and results from X-ray spectroscopy of Sharri cheese at I ${ }^{\text {st }}$ (top) or I 20 (bottom) days of maturation

\section{Conclusion}

The results showed that the manufacturing method of Sharri cheese significantly influenced the volatile components, texture profile and microstructure of cheeses. According to this approaches on the cheese, it can be concluded that high levels of salt resulted in a slow biochemical reactions and formation of volatiles. The use of artisanal technological process for Sharri cheese manufacture with especially more compact protein structure. In the studies of Oluk et al. ${ }^{30}$ large differences between the microstructure of the cheeses were observed with different period of maturation. However, Madadlou et al. ${ }^{31}$ pointed out that Iranian brined cheese with higher concentration of rennet was more compact protein network. The number of openings was higher, probably due to the impact of $\mathrm{NaCl}$ on the hydrophobic interactions of casein. It was found that caseins are homogenously coalesced by $\mathrm{NaCl}$ diffusion during ripening and that chlorides promote a hydrophobic interaction among caseins. ${ }^{32}$

high proportion of acids and wild microbiota is detriment for original flavor characteristic of cheese mainly due to the unbalanced high concentration of short fatty acids. An equilibrated amount of acids with some other volatiles compound such as ketones and aldehydes seems to result in better acceptance of artisanal but an excess of those components causes quality decrease. In conclusion, the use of autochthon manufacture process for Sharri cheeses could help in the maintaining of the indigenous characteristics. 


\section{Acknowledgment}

E. Sulejmani thanks Technological Research Center (TÜTAGEM) at Trakya University, Turkey, for taking SEM pictures of cheese samples.

\section{References}

1. Hassan A, Johnson ME, Lucey JA. Changes in the proportions of soluble and insoluble calcium during the ripening of Cheddar cheese. J Dairy Sci. 2004;87(4):854-862.

2. Mulet A, Escheriche I, Rossello C, et al. Changes in the volatile Fraction during ripening of Mahon cheese. Food Chem. 1999;65(2):219-225.

3. Bodyfelt FW, Tobias J, Trout GM. The sensory evaluation of dairy products Van Nostrand Reinhold. 1988.

4. Luyten J, Plijter JJ, Van Vliet T. Understanding the sensory attributes crispy and crunchy: an integrated approach. In: Proceedings of the 3rd international symposium on food rheology and structure. 2003.p.379-384.

5. Luyten H, Van Vliet T. Effect of maturation on large deformation and fracture properties of (semi-) hard cheeses. Netherlands Milk and Dairy Journal. 1996;50(2):295-307.

6. Zoon P, Allersma D. Eye and crack formation in cheese by carbon dioxide from decarboxylation of glutamic acid. Netherlands Milk and Dairy Journal. 1996;50(2):309-318.

7. Rysha A, Delaš F. Sensory properties and chemical composition of Sharri cheese from Kosovo. Mljekarstvo/Dairy. 2014;64(4).

8. Rysha A, Markov K, Frece J, et al. A survey of the microbiological quality of Sharri, a hard mountain cheese from Kosovo. Int J Dairy Technol. 2014;67(2):277-282.

9. Feratii I, Bijo B, Durmishi N, et al. Monitoring the presence of staphylococcus coagulaso positive in sharri cheese during the traditional ripening. Albanian Journal of Agricultural Sciences. 2012;11(4).

10. IDF (International Dairy Federation). Cheese and processed cheese: moisture determination, determination of the total solids content international dairy federation. International Dairy Federation, Brussels, Belgium. (1982).

11. IDF (International Dairy Federation). Fat, cheese and processed cheese: Determination of fat content, Schmid-Bondzynskiratzlaff method, Standard 5B. International Dairy Federation, Brussels, Belgium. (1986).

12. IDF (International Dairy Federation). Determination of Nitrogen Content, Kjeldahl Method, Standard 20B. International Dairy Federation, Brussels, Belgium. (1993)

13. Sahingil D, Hayaloglu AA, Simsek O, et al. Changes in volatile composition, proteolysis and textural and sensory properties of white-brined cheese: effects of ripening temperature and adjunct culture. Dairy Sci Technol. 2014;94(6):603-623.

14. Hayaloglu AA, Tolu C, Yasar K, et al. Volatiles and sensory evaluation of goat milk cheese Gokceada as affected by goat breeds (Gokceada and Turkish Saanen) and starter culture systems during ripening. J Dairy Sci. 2013;96(5):2765-2780.
15. Urbach G. Relations between cheese flavour and chemical composition. Int Dairy J. 1993;3(4-6):389-422.

1. 16. Tavaria FK, Ferreira AS, Malcata FX. Volatile free fatty acids as ripening indicators for Serra da Estrela cheese. J Dairy Sci. 2004;87(12):4064-4072.

16. House KA, Acree TE. Sensory impact of free fatty acids on the aroma of a model Cheddar cheese. Food Qual Prefer. 2002;13(7):481-488.

17. Ginzinger W, Jaros D, Lavanchy P, et al. Raw milk flora affects composition and quality of Bergkäse. 3. Physical and sensory properties, and conclusions. Le Lait. 1999;79(4):411-421.

18. Buchin S, Delague V, Duboz G, et al. Influence of pasteurization and fat composition of milk on the volatile compounds and flavor characteristics of a semi-hard cheese. J Dairy Sci. 1998;81(12):3097-3108.

19. Carbonell M, Nuñez M, Fernández-García E. Evolution of the volatile components of ewe raw milk La Serena cheese during ripening. Correlation with flavour characteristics. Le Lait. 2002;82(6):683-698.

20. Carbonell M, Nuñez M, Fernández-García E. Seasonal variation of volatile compounds in ewe raw milk La Serena cheese. Le Lait. 2002;82(6):699-711.

21. Kondyli E, Katsiari MC, Masouras T, et al. Free fatty acids and volatile compounds of low-fat Feta-type cheese made with a commercial adjunct culture. Food Chem. 2002;79(2):199-205.

22. Bintsis T, Robinson RK. A study of the effects of adjunct cultures on the aroma compounds of Feta-type cheese. Food Chem. 2004;88(3):435-441.

23. Barbieri G, Bolzoni L, Careri M, et al. Study of the volatile fraction of Parmesan cheese. J Agric Food Chem. 1994;42(5):1170-1176.

24. Cotter PD, Fox PF, Everett DW, et al. Cheese: Chemistry, Physics and Microbiology. Elsevier. 2017.

25. Bertolino M, Dolci P, Giordano M, et al. Evolution of chemico-physical characteristics during manufacture and ripening of Castelmagno PDO cheese in wintertime. Food Chem. 2011;129(3):1001-1011.

26. Mariaca RG, Fernández-García E, Mohedano AF, et al. Volatile fraction of ewe's milk semi-hard cheese manufactured with and without the addition of a cysteine proteinase. Food Sci Technol Int. 2001;7(2):131-139.

27. Creamer LK, Olson NF. Rheological evaluation of maturing Cheddar cheese. J Food Sci. 1982;47(2):631-636.

28. Delgado FJ, González-Crespo J, Cava R, et al. Proteolysis, texture and colour of a raw goat milk cheese throughout the maturation. Eur Food Res Technol. 2011;233(3):483.

29. Oluk AC, Güven M, Hayaloglu AA. Proteolysis texture and microstructure of low-fat Tulum cheese affected by exopolysaccharide-producing cultures during ripening. International Journal of Food Science \& Technology. 2014;49(2):435-443

30. Madadlou A, Khosroshahi A, Mousavi ME. Rheology, microstructure, and functionality of low-fat Iranian white cheese made with different concentrations of rennet. J Dairy Sci. 2005;88(9):3052-3062.

31. Rowney MK, Roupas P, Hickey MW, et al. Salt-induced structural changes in 1-day old Mozzarella cheese and the impact upon free oil formation. Int Dairy J. 2004;14(9):809-816. 